\title{
Effects of Different Plastic Mulching Methods on Soil Water, Temperature and Nitrate Accumulation in a Dryland Winter Wheat Field
}

\author{
Hui-Zhou Gao ${ }^{1}$, Ying-He Xie ${ }^{1}$, Ting-Liang $\mathrm{Li}^{1}$, Xiao-Dong Zhao ${ }^{1}$, Gao Yu ${ }^{1}$, Li Yue $^{1} \&$ Wu-Bin Jia ${ }^{1}$ \\ ${ }^{1}$ College of Resources and Environment, Shanxi Agricultural University, Shanxi, China \\ Correspondence: Ying-He Xie, College of Resources and Environment, Shanxi Agricultural University, Taigu \\ 030801, Shanxi, China. E-mail: xieyinghe@163.com
}

Received: September 8, 2018

Accepted: October 11, $2018 \quad$ Online Published: December 15, 2018

doi:10.5539/jas.v11n1p105

URL: https://doi.org/10.5539/jas.v11n1p105

\begin{abstract}
This study has investigated the effects of two different plastic mulching methods on soil water, temperature, and nitrate $\left(\mathrm{NO}_{3}-\mathrm{N}\right)$ accumulation in a dryland winter wheat field after one-year experiment. The drought-resistant wheat (Triticum aestivum) variety Chang- 8744 was grown by (i) furrow planting with ridge mulching, (ii) bunch planting with flat mulching, and (iii) conventional flat planting without mulching (or control). Results showed that dryland winter wheat effectively utilized soil water down to $2 \mathrm{~m}$ depth, mainly in the first $140 \mathrm{~cm}$. Plastic mulching increased the evapotranspiration during wheat growing season and mostly $\mathrm{r}$ flat plastic mulching, by $\sim 18 \%$ over the value recorded in the control plots. Soil temperature of the $20-40 \mathrm{~cm}$-layer was higher than the one recorded at 5-10 cm depth during seedling-overwintering stages. Ridge plastic mulching and flat plastic mulching increased soil temperatures at $5 \mathrm{~cm}, 10 \mathrm{~cm}$, and $40 \mathrm{~cm}$ depths during seedling-overwintering stages with reference to the control (no mulching), then lowered them at the same depths during reviving-ripening stages. Residual $\mathrm{NO}_{3}-\mathrm{N}$ was always detected in the soil after harvesting irrespective of the mulching method. It was mainly concentrated in the first $-60 \mathrm{~cm}$ accounting for $\sim 50 \%$ of soil $\mathrm{NO}_{3}-\mathrm{N}$ accumulation within the $2-\mathrm{m}$ profile. The highest soil $\mathrm{NO}_{3}-\mathrm{N}$ accumulation occurred under flat plastic mulching, which represented $\sim 107 \%$ of the mean value of the remaining treatments. Finally, flat plastic mulching showed the greatest effects on soil water, temperature, and $\mathrm{NO}_{3}-\mathrm{N}$ accumulation in dryland wheat field.
\end{abstract}

Keywords: evapotranspiration, soil temperature

\section{Introduction}

Dryland winter wheat is one of the major staple crops in China's Shanxi Province, which is a typical rainfed agricultural area. Winter wheat production in this area is constrained by the uneven distribution of precipitation ( $\sim 500 \mathrm{~mm}$ yearly) and its inconsistency with the water requirement of wheat. Therefore, effectively harvesting rainwater, preserving soil moisture, and coupling water with fertilizers is critical for stable production of rainfed winter wheat.

In recent years, mulching techniques have been widely promoted and applied as an important measure to increase soil temperature, preserve soil moisture to ensure optimum crop yields in the rainfed agricultural areas of northern China (Li et al., 2001; Gao et al., 2005; Debashis et al., 2008; Chen et al., 2010). A previous study found that the water consumption (i.e., evapotranspiration) of plastic mulching was significantly higher than that of no mulching during the growing season in Lanzhou, Gansu (Yang et al., 2015). Plastic mulching showed a remarkable effect on harvesting rainfall and effectively increased soil water content in the surface layer in Wuchuan, Inner Mongolia (Wang et al., 2013). Additionally, plastic mulching markedly enhanced crop utilization of soil water in the deep layer in Yangling, Shaanxi (Wang et al., 2004).

Many studies have indicated that plastic mulching can affect the variation in soil temperature. Plastic mulching resulted in an obvious temperature rise in the Jungar Banner of Inner Mongolia; the largest temperature difference was found at $10 \mathrm{~cm}$ and $20 \mathrm{~cm}$ depths, with a temperature increase of $\sim 2.5^{\circ} \mathrm{C}$ ( $\mathrm{Li}$ et al., 2010). Compared with the control (no mulching), plastic mulching also showed a common effect of increasing soil temperature in Yuzhong, Gansu (Cheng et al., 2016). With regard to soil nitrate $\left(\mathrm{NO}_{3}-\mathrm{N}\right)$ accumulation, the highest $\mathrm{NO}_{3}-\mathrm{N}$ concentration was found at the $0-10 \mathrm{~cm}$ depth under plastic mulching treatment in Dingxi, Gansu 
(Zhang et al., 2011). Soil $\mathrm{NO}_{3}-\mathrm{N}$ concentration was influenced by plastic mulching within a range of $0-80 \mathrm{~cm}$ in the loess highland area of northwest China (Wang et al., 2015).

There exist regional differences in the effects of plastic mulching on soil water, temperature, and $\mathrm{NO}_{3}-\mathrm{N}$ accumulation in dryland wheat fields due to different environmental conditions. In the present study, field experiments were conducted during 2014-2015 in a rainfed agricultural area of southern Shanxi, China that aimed at assessing variations in soil water, temperature, and $\mathrm{NO}_{3}-\mathrm{N}$ concentration under two different plastic mulching methods. The results would provide reference data for the high yield and stable production of dryland winter wheat in southern Shanxi, China.

\section{Materials and Methods}

\subsection{Experimental Site}

The experiment was carried out during 2014-2015 in a dry highland wheat area of Dongliang Village, Liujiayuan Town, Hongtong County, Linfen City, Shanxi Province, China. This area has a warm temperate continental monsoon climate with an average annual sunshine of $2419 \mathrm{~h}$. The effective accumulated temperature was $3326.9{ }^{\circ} \mathrm{C}$ and the average annual temperature $12{ }^{\circ} \mathrm{C}$. The frost-free period lasted $180-210$ days, with the average annual rainfall of $\sim 500 \mathrm{~mm}$. The experiemental site's soil was calcareous cinnamon with a medium loam texture. The chemical characteristics of the topsoil before planting are shown in Table 1.

Table 1. Chemical characteristics of the topsoil before planting

\begin{tabular}{|c|c|c|c|c|c|c|c|}
\hline Year & Organic matter & Total N & $\mathrm{NO}_{3}-\mathrm{N}$ & Available P & Available K & Cation exchange capacity & $\mathrm{pH}$ \\
\hline & \multicolumn{2}{|c|}{---------------- g/kg ------------- } & ------ & $--\mathrm{mg} / \mathrm{kg}$ & --------------- & & \\
\hline 2014 & 14.52 & 0.77 & 8.63 & 12.23 & 198.14 & 48.27 & 7.84 \\
\hline
\end{tabular}

\subsection{Experimental Design}

Three treatments were applied in the experiment including (i) control i.e. conventional flat planting without plastic mulching, (ii) furrow planting with ridge plastic mulching, and (iii) bunch planting with flat plastic mulching, with four replications. The experiment was arranged in a randomized complete block design. The elementary plot area was $470 \mathrm{~m}^{2}$. All fertilizers were applied once as basal fertilizers before sowing, and no irrigation was applied during the growing season of wheat. The drought-resistant wheat (Triticum aestivum) variety Chang-8744 was sown at a rate of $150 \mathrm{~kg} / \mathrm{hm}^{2}$ during September 30-October 1, 2014 and harvested on June 7, 2015 for estimation of the whole plot yield (Gao et al., 2016).

For the control, conventional flat planting was conducted with shallow rotary tillage $13 \mathrm{~cm}$ deep before sowing; after breaking the clods and flattening of the soil, seeds were sown with a row spacing of $20 \mathrm{~cm}$. For the ridge mulching, ridges were covered with plastic film and seeds were sown in $30 \mathrm{~cm}$-width furrows at the side of the plastic film; seeds were sown in two rows spaced $20 \mathrm{~cm}$ apart, with a ridge width of $35 \mathrm{~cm}$. For the flat mulching, the whole ground was covered with flat plastic film fixed with an overlying layer of soil approximately $0.5-1 \mathrm{~cm}$ thick; seeds were sown to $3-5 \mathrm{~cm}$ depth, in rows spaced $15-16 \mathrm{~cm}$ apart and bunches spaced $12 \mathrm{~cm}$ apart; the plastic film was $120 \mathrm{~cm}$ wide each lane, with 7-8 rows per lane.

\subsection{Soil Physicochemical Analysis}

Soil samples were collected down to $2 \mathrm{~m}$ depth at $20 \mathrm{~cm}$ intervals before sowing (September 23) and after harvesting (June 7) during the growing season of 2014-2015. Three parallel samples were taken for each treatment. For soil $\mathrm{NO}_{3}-\mathrm{N}$ analysis, $5 \mathrm{~g}$ of fresh soil sample was weighed and transferred into $50 \mathrm{~mL}$ of 0.01 $\mathrm{mol} / \mathrm{L} \mathrm{CaCl} 2$ and oscillated for $30 \mathrm{~min}$. The $\mathrm{NO}_{3}-\mathrm{N}$ concentration in the extracts was measured using an AA3 continuous flow analyzer (Brown rupee, German). Additionally, soil water content was measured by the oven drying method $\left(105^{\circ} \mathrm{C}, 12 \mathrm{~h}\right)$.

$\mathrm{NO}_{3}-\mathrm{N}$ accumulation $\left(\mathrm{kg} / \mathrm{hm}^{2}\right)=$ Soil depth $(\mathrm{cm}) \times$ Bulk density $\left(\mathrm{g} / \mathrm{cm}^{3}\right) \times \mathrm{NO}_{3}-\mathrm{N}$ concentration $(\mathrm{g} / \mathrm{kg}) / 10$.

Soil water content $=($ Quality of aluminum box and soil sample before drying - Quality of aluminum box and soil sample after drying)/(Quality of aluminum box and soil sample after drying - Quality of dry empty aluminum box $) \times 100 \%$.

Evapotranspiration $(\mathrm{mm})=$ Soil water storage in the 2-m profile before sowing - Soil water storage in the 2-m profile at harvesting + Effective precipitation during the growing season of wheat. 
Temperature loggers (TidbiT v2 Temp, Hobo, USA) were installed at $5 \mathrm{~cm}, 10 \mathrm{~cm}, 20 \mathrm{~cm}$, and $40 \mathrm{~cm}$ depths to collect data automatically and continuously. Temperatures were recorded at a frequency of $1 \mathrm{~h}$.

\subsection{Data Analysis}

The experimental data were analyzed using Excel and DPS statistical software.

\section{Results}

\subsection{Effects of Different Plastic Mulching Methods on Soil Water Content}

Soil water content within the 2-m profile of different treatments generally decreased after harvesting compared with values recorded before sowing (Figure 1); this indicated that winter wheat growth could absorb soil water up to a depth of $2 \mathrm{~m}$. The different treatments showed greater effects on soil water content at $0-140 \mathrm{~cm}$ depth, while no major effects were observed at 140-200 cm depth. In particular, flat plastic mulching resulted in the largest reduction in soil water content at $0-140 \mathrm{~cm}$ depth (6-9\%). The surface soil water content in the flat plastic mulching plots decreased after harvesting, probably because only $95.90 \mathrm{~mm}$ of precipitation fell during the wheat growing season and was absorbed for crop growth, thus resulting in the relatively low soil water content in the surface layer at harvest.

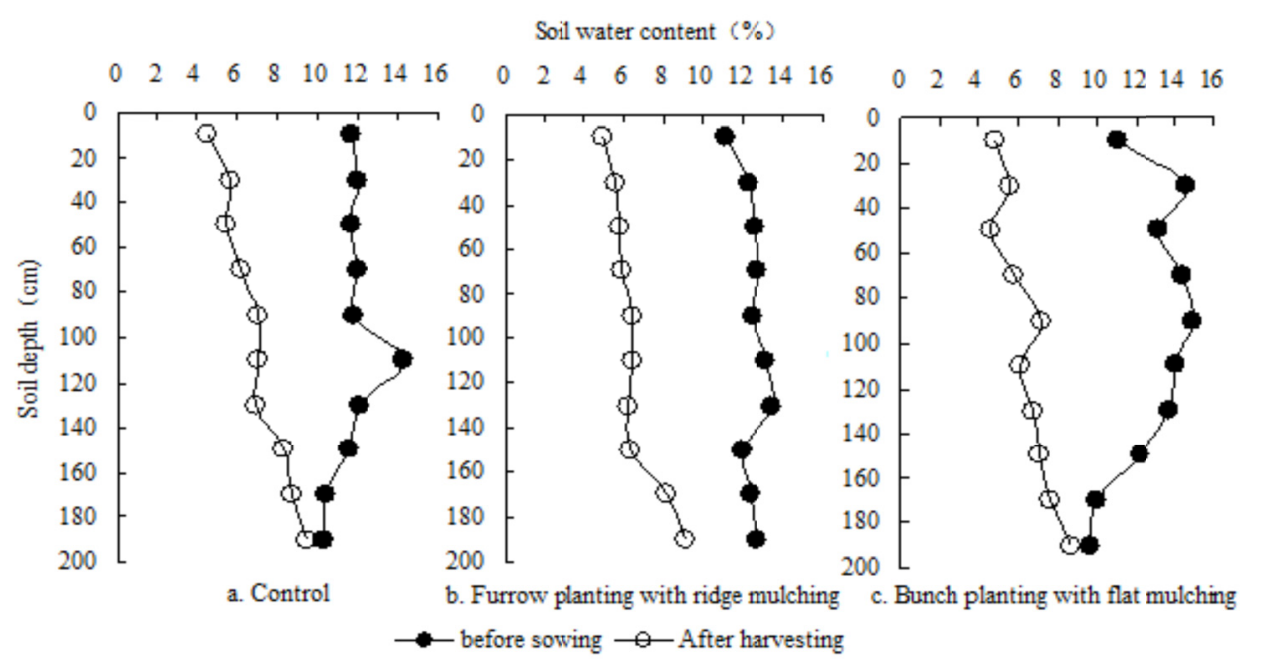

Figure 1. Effect of different plastic mulching methods on soil water content in the 0-200 cm profile

Note. a. Control (before sowing: •); Control (after harvesting: ०); b. Furrow planting with ridge mulching (before sowing: •); Furrow planting with ridge mulching (after sowing: $\circ$ ); and c. Bunch planting with flat mulching (before sowing: •); Bunch planting with flat mulching (after sowing: $\circ$ ).

\subsection{Effects of Different Plastic Mulching Methods on Soil Evapotranspiration}

Estimates of the evapotranspiration of the control, ridge plastic mulching, and flat plastic mulching treatments were $235.08 \mathrm{~mm}, 266.30 \mathrm{~mm}$, and $277.69 \mathrm{~mm}$, respectively. This result indicated that soil evapotranspiration increased with plastic mulching. Significant increases were detected in both the ridge plastic mulching and flat plastic mulching compared to control (no mulching). In fact, ridge plastic mulching increased the evapotranspiration by $\sim 13 \%$ and flat mulching by $\sim 18 \%$. These results indicated that following plastic mulching, the consumption of soil water was conducive to downward root growth of the crops and the absorption of soil water in the deep layers.

\subsection{Effects of Different Plastic Mulching Methods on Soil Temperature}

In mulched plots, soil temperature ranged from 6.1 to $10.4{ }^{\circ} \mathrm{C}$ in November and gradually decreased from December to January, followed by a rebound in February and then a peak in June. At $5 \mathrm{~cm}$ and $10 \mathrm{~cm}$ depths, the soil temperature of flat plastic mulching plots was higher than those of ridge plastic mulching and non-mulched plots during the period of November-February (overwintering stage); the mean temperature increases were $0.3-0.9{ }^{\circ} \mathrm{C}$ at $5 \mathrm{~cm}$ depth and $0.3-0.8{ }^{\circ} \mathrm{C}$ at $10 \mathrm{~cm}$ depth. The soil temperature of the control plots increased compared with those of mulched plots during March-June; mean temperature increases at $5 \mathrm{~cm}$ and $10 \mathrm{~cm}$ depths were $0.1-0.8{ }^{\circ} \mathrm{C}$ and $0.1-0.7{ }^{\circ} \mathrm{C}$ in March (reviving stage), and $0.9-1.7{ }^{\circ} \mathrm{C}$ and $0.9-1.6{ }^{\circ} \mathrm{C}$ during April-June 
(jointing-ripening stages), respectively. At $20 \mathrm{~cm}$ soil depth, soil temperature of the control increased by $0.6{ }^{\circ} \mathrm{C}$ in November-February and by $0.4{ }^{\circ} \mathrm{C}$ in March, whereas the soil temperature of flat mulched plots increased by an average of $0.9^{\circ} \mathrm{C}$ during April-June compared to mean value of the remaining treatments. At $40 \mathrm{~cm}$ soil depth, the soil temperature under flat mulching increased by $0.7{ }^{\circ} \mathrm{C}$ during November-February and by $0.2{ }^{\circ} \mathrm{C}$ in March, while the soil temperature of control treatment increased by an average of $0.8^{\circ} \mathrm{C}$ during April-June compared with the remaining treatments. Thus, bunch planting with flat plastic mulching had a significant effect on heat preservation in the deep soil layer $(40 \mathrm{~cm})$ during the overwintering stage; in the middle-late growth stages of wheat with increasing air temperature, the no mulching treatment showed the greatest temperature-increasing effect, while the plastic mulching treatments exhibited a temperature-reducing effect.
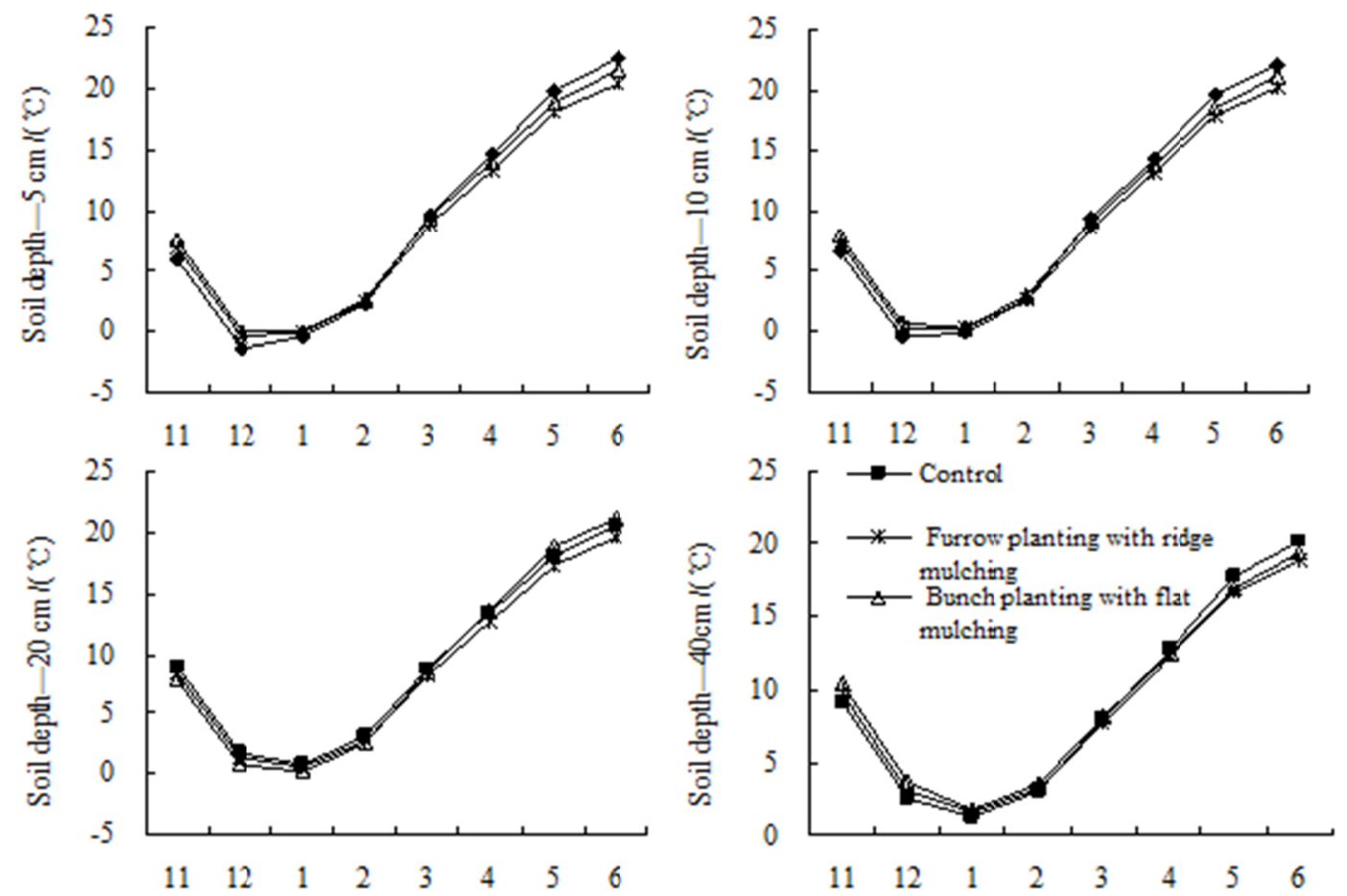

Figure 2. Variation of soil temperature of $0-40 \mathrm{~cm}$ topsoil under the two plastic mulching methods and no mulching

\subsection{Effect of Different Plastic Mulching Methods on Soil $\mathrm{NO}_{3}-\mathrm{N}$ Accumulation}

Degrees of $\mathrm{NO}_{3}-\mathrm{N}$ accumulation in the $0-200 \mathrm{~cm}$ soil profile varied among different treatments after harvesting compared to amounts of $\mathrm{NO}_{3}-\mathrm{N}$ observed before sowing (Figure 3). Higher accumulation occurred at $-100 \mathrm{~cm}$ depth, with little difference at 100-200 cm depth. Maximum $\mathrm{NO}_{3}-\mathrm{N}$ accumulation ranged from 29.19-32.65 $\mathrm{kg} / \mathrm{hm}^{2}$ at $20-40 \mathrm{~cm}$ depth. At 0-60 cm depth, the largest increase in $\mathrm{NO}_{3}-\mathrm{N}$ accumulation was found under flat plastic mulching, i.e. $5.96-7.73 \mathrm{~kg} / \mathrm{hm}^{2}$, whereas the smallest increase $\left(0.72-4.16 \mathrm{~kg} / \mathrm{hm}^{2}\right)$ was found under ridge mulching, as compared with the corresponding level before sowing. At $60-100 \mathrm{~cm}$ depth, the $\mathrm{NO}_{3}-\mathrm{N}$ accumulation under flat plastic mulching increased by $2.75-5.81 \mathrm{~kg} / \mathrm{hm}^{2}$ compared with the level before sowing, while ridge mulching resulted in the largest increase in $\mathrm{NO}_{3}-\mathrm{N}$ accumulation $\left(3.88-6.72 \mathrm{~kg} / \mathrm{hm}^{2}\right)$. At depths below $100 \mathrm{~cm}$, soil $\mathrm{NO}_{3}-\mathrm{N}$ accumulation decreased to different degrees under both ridge plastic mulching and flat plastic mulching, but the relative decrease was larger in the latter treatment, in absolute terms (Figure 3).

Our results showed that following plastic mulching, $\mathrm{NO}_{3}-\mathrm{N}$ accumulation increased at 0-100 cm- soil depth, while no major difference was found at $100-200-\mathrm{cm}$ soil depth. This may be due to the fact that at the later growth stages of wheat, the roots grew downward and promoted nutrient absorption in the lower soil layers, thus resulting in decreased $\mathrm{NO}_{3}-\mathrm{N}$ accumulation in the deep soil. By contrast, $\mathrm{NO}_{3}-\mathrm{N}$ accumulation reached a peak at 20-40 cm depth, which may be attributable to precipitation that caused $\mathrm{NO}_{3}-\mathrm{N}$ leaching loss from $0-20 \mathrm{~cm}$ soil depth and subsequent accumulation toward $20-40 \mathrm{~cm}$ soil depth. For the flat mulching, $\mathrm{NO}_{3}-\mathrm{N}$ accumulation mainly occurred at 0-60 $\mathrm{cm}$ depth, while it was slightly decreased at $60-100 \mathrm{~cm}$ depth. There was little residual $\mathrm{NO}_{3}-\mathrm{N}$ at $100-200 \mathrm{~cm}$ depth after harvesting, indicating that flat plastic mulching was conducive to nutrient 
absorption by wheat from the deep soil; this may be due to the fact that the migration of $\mathrm{NO}_{3}-\mathrm{N}$ occurred with the movement of water. Following plastic mulching, the increase in crop yields was related to downward root growth of the crops, which could absorb and utilize water and nutrients in the deep soil (Cao et al., 2014).

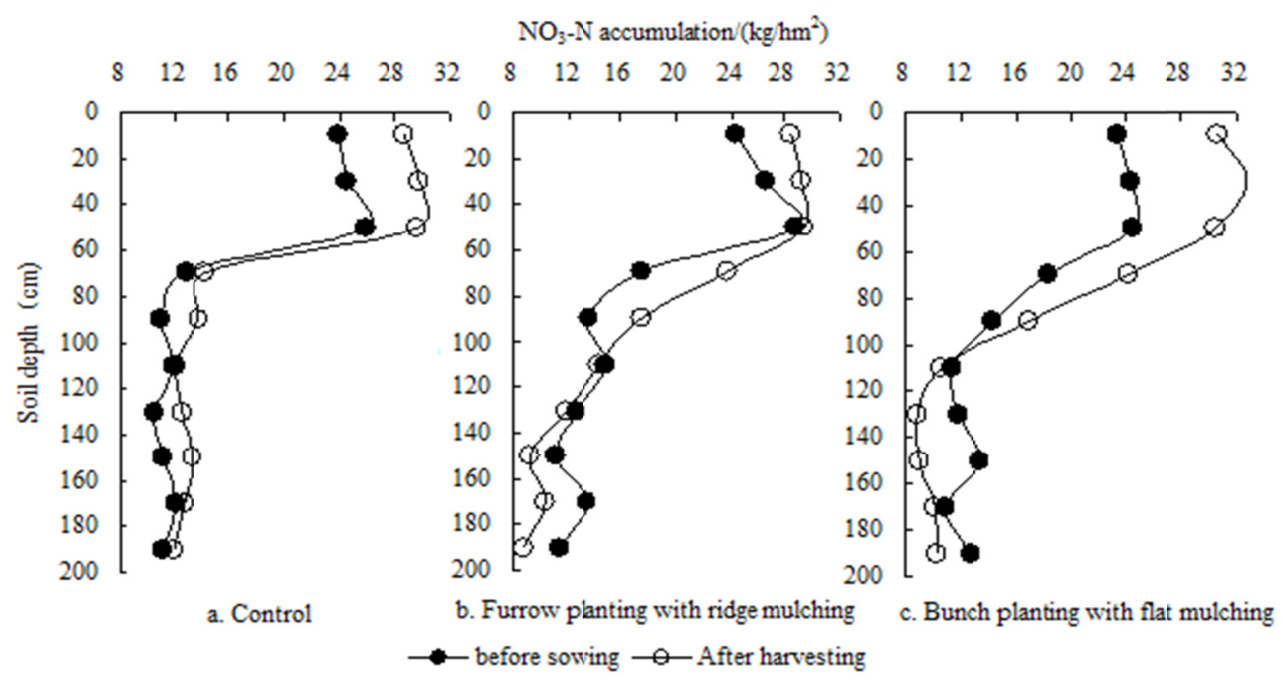

Figure 3. Effects of different plastic mulching methods on $\mathrm{NO}_{3}-\mathrm{N}$ accumulation in the $0-200 \mathrm{~cm}$ soil profile

Note. a. Control (before sowing: •); Control (after harvesting: ०); b. Furrow planting with ridge mulching (before sowing: •); Furrow planting with ridge mulching (after sowing: $\circ$ ); and c. Bunch planting with flat mulching (before sowing: •); Bunch planting with flat mulching (after sowing: $\odot$ ).

\section{Discussion and Conclusion}

This study showed that plastic mulching reduced water evaporation and preserved soil water, which is in agreement with previous research on plastic film mulching. Our results showed that evapotranspiration was mainly concentrated to the top $0-140 \mathrm{~cm}$ of the soil under bunch planting with flat plastic mulching in wheat field in south Shanxi. Yang et al. (2011) showed that plastic mulching was conducive to increasing soil water content and promoting the expansion of soil water reservoir capacity. Li et al. (2011), and Ren et al. (2010) showed that under furrow-ridge mulching, natural precipitation was effectively stored and infiltration was enhanced, which significantly increased soil water storage in dryland wheat fields. By comparison, bunch planting with flat plastic mulching contributed to water storage and preservation to a greater degree. He et al. (2010) showed that bunch planting with whole plastic mulching contributed to rainwater harvesting and soil water preservation to a maximized degree. Song et al. (2014) conducted bunch planting with whole plastic mulching in dryland wheat field in a semi-arid area for two consecutive years and found the depth of evapotranspiration extended to $200 \mathrm{~cm}$.

Different mulching techniques can induce variations in soil temperature among other parameters. In fact, plastic mulching reduces soil water evaporation and increase surface soil temperature (Licht et al., 2005; Zhao et al., 2011). Chen et al. (2009) showed that at the overwintering stage, soil temperature in the deep layer was higher than that in the surface layer. This is generally consistent with our results whereby bunch planting with flat plastic mulching had a significant effect on the preservation of soil heat in the deep layer $(40 \mathrm{~cm})$ during the overwintering stage. In the present study, it was found that soil $\mathrm{NO}_{3}-\mathrm{N}$ accumulation in the 2-m profile of plastic mulching treatments increased after harvesting compared to before sowing, but was mainly concentrated 0-100 $\mathrm{cm}$ depth. Under bunch planting with flat plastic mulching, $\mathrm{NO}_{3}-\mathrm{N}$ mainly accumulated at 0-60 $\mathrm{cm}$ depth, with little $\mathrm{NO}_{3}-\mathrm{N}$ residue was found in deep soil layers.

Gao et al. (2005) showed that following plastic mulching, residual $\mathrm{NO}_{3}-\mathrm{N}$ was mainly concentrated in the 0-100 $\mathrm{cm}$ soil layer in wheat field. Chen et al. (2011) reported that soil $\mathrm{NO}_{3}-\mathrm{N}$ mainly accumulates above $60 \mathrm{~cm}$, while it decreases in deep layers gradually under different ridge-furrow cultivation patterns in the Weibei highland area. Xie et al. (2015) concluded that bunch planting with whole plastic mulching markedly reduces $\mathrm{NO}_{3}-\mathrm{N}$ accumulation in deep soil. 
Although this study only presented the experimental results of one year, the findings were generally consistent with those from other local experimental studies by Li et al. (2011), Xie et al. (2011), Feng (2013), and Zhao et al. (2015) and showed certain trends. All the findings indicated that plastic mulching could improve winter wheat yield, regulate soil temperature, increase soil water, and promote crop absorption and utilization of water and nutrients.

\section{References}

Cao, H. B., Wang, Z. H., Shi, Y. C., Du, M. Y., Lei, X. Q., Zhang, W. Z., .. Fu, Y. J. (2014). Optimization of nitrogen fertilizer recommendation technology based on soil test for winter wheat on Weibei dryland. Scientia Agricultura Sinica, 47(19), 3826-3838.

Chen, H. L., Liu, T., Tian, X. H., Zhao, A. Q., \& Wang, Z. H. (2011). Effects of different cultivation modes on soil water, yield and $\mathrm{NO}_{3}-\mathrm{N}$ accumulation in Weibei Loess Plateau. Agricultural Research in the Arid Areas, 29(5), 19-25.

Chen, H. L., Tian, X. H., Wang, X. F., Cao, Y. X., Wu, Y. H., \& Wang, Z. H. (2010). Effects of different cultivation models on soil water,soil temperature and yield during the winter wheat growth in the Weibei Dry Highland. Acta Ecologica Sinica, 30(9), 2424-2433.

Chen, J. K., Li, S. J., Zhang, Y., Chen, F., \& Zhang, H. L. (2009). Characteristics of soil temperature and response to air temperature under different tillage systems-diurnal dynamic of soil temperature and its response to air temperature. Scientia Agricultura Sinica, 42(7), 2592-2600.

Cheng, H. B., Niu, J. B., Chai, S. X., Chang, L., \& Yang, C. G. (2016). Effect of different mulching materials and methods on soil moisture and temperature and grain yield of dryland spring wheat in northwestern China. Acta Prataculturae Sinica, 25(2), 47-57.

Debashis, C., Shantha, N., Pramila, A., Guptaa, V. K., Tomara, R. K., Garg, R. N., ... Kalra, N. (2008). Effect of mulching on soil and plant water status, and the growth and yield wheat (Triticum aestivum L.) in a semi-arid environment. Agric Water Manage, 95(12), 1323-1334. https://doi.org/10.1016/j.agwat.2008. 06.001

Feng, Q. (2013). Effects of different plastic film mulching cultivation on yield, water and nutrient utilization of wheat in dry highland of southern Shanxi (Dissertation, Shanxi Agricultural University).

Gao, H. Z., Xie, Y. H., Li, T. L., Zhao, X. D., Yu, G., Yue, L., \& Jia, W. B. (2016). Effects of plastic film mulching on grain yield and soil moisture dynamics in dryland winter wheat. Journal of Shanxi Agricultural Sciences, 44(12), 1793-1795, 1869.

Gao, Y. J., Li, Y., Li, S. X., Qiang, Q., Cao, W. X., Liu, W. G., ... Liu, J. H. (2005). Effects of different wheat cultivation methods on residual nitrate nitrogen in soil in dryland. Acta Ecologica Sinica, 25(11), 2901-2910.

He, C. Y., Zhou, X. C., Du, J. Y., Lu, Q. L., Zhang, L. J., Zhou, J., ... Zhou, G. (2010). Study on Winter Wheat Yield under Technology of No-Tillage, Bunch-Planting, Whole Film and Soil Mulching During Whole Growth. Research of Agricultural Modernization, 31(6), 746-749.

Li, R., Cui, R. M., Jia, Z. K., Han, Q. F., Lu, W. T., \& Hou, X. Q. (2011). Effects of Different Furrow-ridge Mulching Ways on Soil Moisture and Water Use Efficiency of Winter Wheat. Scientia Agricultura Sinica, 44(16), 3312-3322.

Li, S. Q., Li, F. M., Song, Q. H., \& Wang, J. (2001). Effects of plastic film mulching periods on the soil nitrogen availability in semiarid areas. Acta Ecologica Sinica, 21(9), 1519-1526.

Li, T. L., Xie, Y. H., Hong, J. P., Liu, L. P., Meng, H. S., Deng, S. Y., ... Sun, C. H. (2011). Effects of topdressing nitrogen and plastic film mulched ridge-sowing furrow cultivation on nitrogen utilization of winter wheat on rainfed lands in Southern Shanxi. Plant Nutrition and Fertilizer Science, 17(6), 1300-1308.

Li. X., Cheng, M. J., Gou, M. M., \& Song, Y. X. (2010). Variation of soil temperature about plastic film mulching Maize in semi-arid Areas, the Loess plateau. Ecology and Environment, 19(1), 218-222.

Licht, M. A., \& Al-Kaisi, M. (2005). Strip-tillage effect on seedbed soil temperature and other soil physical properties. Soil and Tillage Research, 80(1-2), 233-249. https://doi.org/10.1016/j.still.2004.03.017

Ren, X. L., Jia, Z. K., \& Chen, X. L. (2010). Effect of micro-catchment rainwater harvesting on water and nutrient use efficiency in farmland under different simulated rainfall conditions. Transactions of the Chinese Society of Agricultural Engineering, 26(3), 75-81. 
Song, T., Wang, H. Y., Chen, N. L., \& Zhang, X. C. (2014). Regulation of whole field soil-plastic mulching with bunch planting and whole field sand mulching with flat planting on soil moisture and yield of spring wheat in semiarid dryland areas. Chinese Journal of Eco-Agriculture, 22(10), 1174-1181.

Wang, C. R., Tian, X. H., \& Li, S. X. (2004). Effects of plastic sheet-mulching on ridge for rainwater-harvesting cultivation on WUE and yield of winter wheat. Scientia Agricultura Sinica, 37(2), 208-214.

Wang, X. M., Li, Z. B., \& Xing, Y. Y. (2015). Effects of mulching and fertilization on maize yield, soil temperature and nitrate- N distribution. Plant Nutrition and Fertilizer Science, 21(04), 884-897.

Wang, Y. H., Meng, M. L., Chen, Y. J., Zhang, J., Wang, Z. X., \& Cui, C. L. (2013). Effect of different film-covering modes on the yield and soil moisture of dry land tillage potato. Chinese Agricultural Science Bulletin, 29(3), 147-152.

Xie, Y. C., Zhang, P. L., Guo, T. W., Jiang, X. F., \& Hou, H. Z. (2015). Effect of Film-mulching on Nitrate and Ammonium Nitrogen in Dryland Wheat Fields. Journal of Triticeae Crops, 35(6), 836-843.

Xie, Y. H., Li, T. L., Hong, J. P., Liu, L. P., Pang, J., Feng, Q., ... Shan, J. (2011). Effects of nitrogen application and ridge film furrow planting on water use of winter wheat in dry land of South Shanxi. Chinese Journal of Applied Ecology, 22(08), 2038-2044.

Yang, C. G., Chai, S. X., \& Chang, L. (2015). Influences of different plastic film mulches on soil water use and yield of winter wheat in semiarid rain-fed region. Acta Ecologica Sinica, 35(8), 2676-2685.

Yang, H. D., Hai, J. B., Jia, Z. K., Han, Q. F., Zhang, B. J., \& Ren, S. C. (2011). Effect of different plastic-film mulching in the whole growth period on soil moisture and water use efficiency of winter wheat. Agricultural Research in the Arid Areas, 29(2), 27-34.

Zhang, X. M., Huang, G. B., Li, L. L., Xie, J. H., \& Chen, H. (2011). Effects of mulching patterns on spatio-temporal variation of soil nitrate and nitrogen utilization efficiency of maize on dry land. Agricultural Research in the Arid Areas, 29(5), 26-32.

Zhao, H., Xiong, Y. C., Li, F. M., Wang, R. Y., Qiang, S. C., Yao, T. F., \& Mo, F. (2011). Plastic film mulch for half growing-season maximized WUE and yield of potato via moisture-temperature improvement in a semi-arid agroeco-system. Agricultural Water Management, 104, 68-78. https://doi.org/10.1016/j.agwat. 2011.11.016

Zhao, X. D., Xie, Y. H., Li, T. L., Feng, Q., Wen, D. Z., He, L. Y., \& He, J. (2015). Effect of plastic film mulching on soil moisture and available nutrient content of winter wheat on rainfed lands in southern Shanxi. Journal of Shanxi Agricultural University (Natural Science Edition), 35(03), 262-265, 289.

\section{Copyrights}

Copyright for this article is retained by the author(s), with first publication rights granted to the journal.

This is an open-access article distributed under the terms and conditions of the Creative Commons Attribution license (http://creativecommons.org/licenses/by/4.0/). 